\title{
The Donner Institute for \\ Research in Religious and Cultural History
}

\author{
by HELMER RINGGREN
}

The Donner Institute is an institution for the study of the history of religion and culture at the university of $\AA$ bo Akademi ( $\AA$ bo, Finland). It was founded in 1957 following a stipulation in the last will of Mr. and Mrs. Uno Donner of Helsingfors, who died in 1958 and 1956 respectively.

Uno Donner was an engineer who had studied in Finland, England and Germany, and was a prominent industrial leader in Finland. He was also a painter whose works were well above the amateur level. His wife Olly, née Sinebrychoff, was of an originally Russian family, also prominent in Finnish industry. She was a prolific writer, who published a great number of novels, plays, and short stories in Swedish and French without, however, receiving much attention from the critics. Her interests included such authors as Hölderlin, Nietzsche, William Blake, and Rilke.

Uno Donner had shown an early interest in philosophical questions. During a visit to Egypt at the beginning of this century both he and his wife were impressed by ancient Egyptian culture and certain mysterious aspects of religion. They both seem to have had a firm conviction that intuition is an important way to true knowledge. When, in 1913 , an artist friend of theirs, Henry Collison, introduced them to the thinking of Dr. Rudolf Steiner, their interest was easily kindled, and they became eager students af anthroposophy. They visited Dornach near Basel, the center of the anthroposophic movement, several times and made the personal acquaintance of Dr. Steiner. When an Anthroposophic Society was established in Finland in 1922, Uno Donner became its president.

Convinced as he was of the existence of a supersensory world, Uno Donner was unwilling to accept any doctrines about it on the mere authority 
of established religion or philosophical speculation. No doctrine could be considered final or be said to contain the whole truth. He was anxious that religious and philosophical ideas should be subjected to earnest research for verification or disproof. On the other hand, he was convinced that philosophical intuition and religious experience had played an extremely important part in the cultural evolution of humanity.

It is against this background that we have to consider his decision to give his property to a foundation for the study of religion. The will provides for the establishment of an institute "to promote the strictly scientific study of the history of religion and culture with special regard to the influence of mystery religions and occultism on the origin and development of various religions and cultures". It was also recommended to include the study of "modern phenomena in religion, philosophy, science, art, and literature, in which mysticism and occultism have asserted themselves". Accordingly, the statutes of the Donner Institute defines the scope of the foundation as "the promotion of the scientific investigation of the mystic experience and its significance for the origin and development of the various forms of religion and culture".

The above wording placed the executors of the will before a puzzling task. In general usage, "mysticism" and "mystery religions" have nothing but their Greek etymology in common. The statutes with their reference to the mystic experience represent a kind of compromise, but even so the aim of the foundation remains somewhat obscure.

However, the suspicion was near at hand that the clue to Mr. Donner's combination of the words "mystery" and "mysticism" is to be found in anthroposophic usage. This suspicion turned out to be true. According to the anthroposophic view of history, there have been in the various epochs of the earth's evolution "mystery places", where the truths of the supersensory world were cultivated and taught, and the Hellenistic mystery religions are late and imperfect representatives of the wisdom taught at those mystery places. "Mysticism" and "mystic", on the other hand, refer, according to some statements in the introduction to Dr. Steiner's Das Christentum als mystische Tatsache, to any experience that derives from the supersensory and brings man into touch with the realities of the supersensory world. True occultism, according to the same source, is more or less identical with 
this mysterious wisdom and is by no means incompatible with true mysticism.

But what has this to do with the history of religion and culture? Again, anthroposophy provides us with a clue. According to Dr. Steiner, the actual religions of the world are poor remains or survivals of the knowledge that mankind has once possessed about the supersensory world. True art, in all its manifestations, is equally an cffluence of man's experience of the supersensory. Consequently, religion and culture are results of the mystic experience, understood as the experience of the supersensory.

True to these intentions, the Donner Institute has set up as its goal to promote all kinds of study within the realm in which the mystic experience manifests itself in various ways, in mysticism, in all kinds of religious practice, in art, literature, and other cultural activities. The only limitation set up is that in some way or other an experience that is understood as supersensory should be present.

In accordance with the expressed wish of the donor, special attention is given to the study of the ideas of Rudolf Steiner. The library of the institute possesses an almost complete collection of Dr. Steiner's works and all available works of various anthroposophic authors. The fascinating study of Dr. Steiner's ideas in the areas of philosophy, religion, history, medicine, education, biology, politics, etc., has only begun, but anyone who is willing to engage himself in such study will here find rich opportunities of broadening his perspectives.

The Donner Institute tries to realize its task in various ways. First and foremost, according to the wish of the donors, comes the library, called The Steiner Memorial Library. Started in 1957 , it has grown in a most satisfactory way and contains today approximately I3,000 volumes. Covered are all branches of the history of religions, including the psychology, phenomenology and sociology of religion, occultism, superstition, folklore, history of medicine, etc. Recently the possibilities of study and research have been greatly enriched through moving into new and more spacious localities, enabling students to work in the library itself with access to all its treasures.

Secondly, scholarships are distributed every year to people who carry out research in any of the fields that are within the Institute's sphere of interest. In the last five years the annual amount of scholarships has been $20,000 \mathrm{FMk}$, 
in addition to which special grants have been given to the Scandinavian Nubia expedition, for the printing of a collection of Pythagoraean texts, and for the promotion of folkloristic studies at the Abo Akademi.

Thirdly, a chair of comparative religion has been established at the Åbo Akademi. As the first professor was appointed, in 1962, Dr. Helmer Ringgren, who earlier taught comparative religion at the University of Uppsala and Old Testament Interpretation at Garrett Theological Seminary, Evanston, Ill., U.S.A. This was the first time comparative religion was taught as a regular subject at a university in Finland, and considering the relatively small number of students studying at the Abo Akademi, the interest taken in this new branch of study has been most encouraging. As Prof. Ringgren moved to Sweden in 1965 , he was succeeded by Dr. Sven S. Hartman.

A fourth branch of activity is the organization of symposia. The aim of these symposia is to bring together specialists from different fields of study to discuss problems of religion, each elucidating them from his particular point of view. In this age of specialization this combination of approaches seems to be a very valuable method of studying a phenomenon of such a complex nature as religion. To this date two symposia have been held; one in 1962 on shamanism and the other in 1964 on ideas of destiny. The proceedings of the symposia will be printed as volumes in a series of publications, published by the Donner Institute under the title Scripta Instituti Donneriani Aboensis. 